\title{
構造化手法による交通施設整備と産業構造変化 との関連分析
}

\section{徳永幸之*・稲村 肇**・須田 熙**. 安井誠一郎 ${ }^{* * *}$}

\begin{abstract}
本研究では, 産業取引構造の変化之交通施設整備との関連を分析する方法について議 諭している。産業構造の構造化手法として FSM 法を適用し，指標值には産業連関表の 投入係数と産出係数の最大值を使用した。 さらに, 自給率を考慮することにより, 地域 外の産業との取引構造の変化を明示的に扱っている. 交通施設整備前後の産業取引構造 を比較することにより, 産業構造変化と高速道路等の交通施設整備との関連について考 察することが可能となる. 適用例として東北 4 県の分析を行った.
\end{abstract}

Key Words : structural modeling, Input-Output structure, transportation facility

\section{1. 本研究の背景と目的}

国土の均衡ある発展を目指した交通施設整備が行われ てきたにも拘らず地域間隔差は縮まっていない。これは, 交通施設整備を核とした地域開発政策において地域の産 業構造を十分考慮していなかったことにも一因があろ う. 高速道路のような交通施設整備は地域間の産業間取 引の構造を変化させ, その結果として地域に経済的便益 をもたらすと考えられる. 従来の交通施設整備の評価手 法においては最終的な経済的便益を計測することに主眼 をおいているために，その過程にある産業間の取引変化 については明確にされていなかった。しかし，今後の交 通施設整備と地域開発政策を考える上では交通施設整備 と産業間の取引変化の関係を明確にしておく必要があ る.

産業連関表は産業の構成だけでなく産業間の取引関係 までも網羅的に表すものである. 産業間の取引関係を示 す投入係数の変化に関しては $2 つ$ 側面から研究がなさ れてきた.すなわち, 産業連関モデルの安定性に関する 側面と, 経済発展に伴う構造の変化に関する側面である.

産業連関分析は投入係数の安定性を前提に均衡生産額 の推計等を行うため, 投入係数の変化は推計誤差の面か ら関心が持たれ，係数変化の要因に関しても実証的分析 が数多く行われてきた1),2). また，Buckley $(1989)^{31}$ は 投入係数の不確かさに対してファジィ数を導入してい る.

経済発展に伴う産業構造の変化に関する研究には静学 モデルに基づくものと動学モデルに基づくものがある. 静学モデルに基づくものとして, Leontief $(1953)^{4}$ は

\footnotetext{
*正会員 東北大学助手 工学部土木工学科

( 于980 仙台市青葉区荒巻字青葉)

**正会員 工博 東北大学教授 工学部土木工学科

****学生員 東北大学大学院 土木工学専攻
}

個々の投入係数の変化により産業構造の変化を分析して いる.また, Hirschman (1958) $)^{5)}$ や Rasmussen $(1956)^{6)}$ はそれぞ投入孫数及び逆行列係数の行和・列和を用い て産業構造を分析する方法を提案し, Chenery \& Watanabe $(1958)^{7)}$ や金子 $(1983)^{8)}$ らはこれらの実証的分析 を行っている、しかし，これらの方法はある産業が経済 全体に及ぼす影響あるいは受ける影響を定量化するもの であり，産業間相互の関係については分析していない. 一方, 資本ストックを内生化して変動過程を分析するモ デルの動学化が Leontief $(1953)^{9)}$ をはじめ多くの研究 者により行われている. Morishima (1958) ${ }^{10)}$ や Solow $(1959)^{11)}$ らは投入係数の変化を相対価格の変化による 技術代替として捉え, 最適均衡成長経路を求めている. また，Leontief $(1970)^{12)}$ は投入及び資本係数の変化に よる生産構造の時間的連鎖を明らかにし, 尾崎 $(1979)^{13 \prime}$ は技術係数変化の要因分析を行っているが，やはり産業 間相互の関係については分析されていない.

産業間相互の連関構造を容易に把握可能とするために はグラフにより視覚情報に変換する方法が有効である. グラフ理論を産業構造分析に適用した研究にはCampbell $(1975)^{1+1}$ や Slater $(1977)^{15)}$ をはじめ多々あるが, これらの研究は産業間の関係を有無の 2 值で表現してお り，関係の強弱が考慮されていない，著者ら (1991) は，構造化手法にファジィ概念を用いたF S M法を適用 することにより関係の強弱を考慮した産業立地分析を 行っている. しかし, これらの研究は 1 時点の分析のみ にとどまり，構造の変化については言及していない.

本研究は, 地域の産業構造を交通施設整備の前後で比 較することにより, 交通施設整備と産業構造変化との関 連を明確にすることを目的としている．従来の産業構造 分析では地域間の産業間取引の変化を明示していなかっ たが, 本研究では域内品と移入品を区別することにより， 産業構造変化と交通施設の関係をより明確にすることを 
試みる。産業構造変化の把握には，筆者らが産業立地分 析に適用したFSM 法を用いるが，本研究はこれを 2 断 面分析に拡張したものである. また，FSM 法を産業構 造分析に適用する場合の問題点及びその対処方法につい ても考察している.なお，ここで用いているファジィ理 論の応用の方法 ${ }^{17)}$ は, ファジィ関係と合成演算を用いて 産業間の関係を記述しようとするものであり, Buckley のファジィ産業連関モデルとはその目的, 応用の方法と もに異なったものである. 最後に，適用例として東北地 方の 4 県における産業構造の変化と交通施設整備の関係 について考察する.

\section{2. 本研究の考え方}

\section{（1）構造化手法}

構造化手法には ISM (Interpretive Structural Modeling) 法 ${ }^{18)}$, FSM (Fuzzy Structural Modeling) 法 ${ }^{19)}$, DEMATEL (Decision Making Trial and Evaluation Laboratory）法"01など多々ある.これらの手法の特徴は 以下のとおりである.

(1) ISM 法は要素間の関係を有無の 2 値で扱うのに 対し, FSM 法及び DEMATEL 法は連続值として扱 うため, 関係の強弱を考慮できる.

(2) ISM 法は間接的影響があれば直接的関係を無条 件でカットするが，FSM 法はしきい值とあいまい構 造パラメータの関係によって間接的関係と直接的関係 のバランスを変えた構造を同定することができる.

(3) DEMATEL 法は間接的影響を直接的影響に加え た総合影響指標に基づき構造化を行うため, 直接取引 のない産業間の関係まで構造化する恐れがある.

産業構造化においては, 関係の強弱を考慮でき, 分析 目的に応じて間接的関係と直接的関係のバランスを変 えることのできるFSM 法が適している.

(2)で述べた FSM 法の特性はFSM 法の構造同定にお いて直接的関係を式（1）により計算される間接的関係 のあいまい補集合との最小值で置き換えることに起因し ている.

$\overline{a_{i j}}=\frac{1-a_{i j}}{1+\lambda a_{i j}}$

ここで, $a_{i j}$ : 従属関係行列の要素

$$
\begin{gathered}
\lambda: \text { あいまい構造パラメータ } \\
\quad(-1<\lambda<\infty)
\end{gathered}
$$

間接的関係がしきい値 $p$ の $k$ 倍の亡き直接的関係を 残すためには式（2）の条件を満たせばよい.したがっ て, このときの限界となる入は式（3）によって求め られる。

$$
\frac{1-k p}{1+\lambda k p}=p
$$

$$
\lambda=\frac{1-(1+k) p}{k p^{2}} .
$$

$k \geqq 1 / p$ さきは間接的関係の有無にかかわらずしきい 值以上の直接的関係は全てグラフ化される. $k=1$ のと きはしきい值以上の間接的関係があれば直接的関係を カットする ISM 法と同様の結果が得られる. $k<1$ とす るとしきい值以下の間接的関係，即ちグラフ化されない 間接的関係により直接的関係がカットされ，本来関係の ある産業が連結されなくなる問題が生じる.よって，産 業構造分析においては $1 \leqq k \leqq 1 / p$ の範囲で $\lambda$ を設定す ればよい．この範囲で入をいくらに設定するかは産業 構造化の目的によって異なる．産業群の構成を目的とす る場合には直接的関係がカットされても間接的関係に よって産業群が構成されれば十分であるため, $k=1$ と した入の值とすればよい。一方，産業間の取引を忠実 に構造化したい場合には間接取引があっても直接取引も 構造化する必要があるため, $k=1 / p$ とした $\lambda$ の值とす ればよい．これらは両極端な例であるが，投入・産出係 数は直接取引の係数が大きくなれば間接取引の係数は小 さくなる関係にあるため，これらの中間的な入の值の ときに直接取引が多ければその関係を残した構造図, 即 ち関係の強弱を考慮した構造図を作成することができ る.

しきい值 $p$ と構造化されるグラフ数の関係について, 部門数 $n$ を変えた投入・産出係数によって検討した. 各部門数とも $p=2.5 / n$ 程度でグラフ数が部門数と等し くなり，しきい值をこれより小さくすると急激にグラフ 数が増加する.グラフ数が部門数より多い構造図はグラ フが複雑に交錯し合い，視覚的に構造を把握することが 困難となる.したがって, 視覚的に構造を把握するため には $p=2.5 / n$ 以上とすればよい.

\section{(2) 構造化の指標}

産業連関表に基づく産業構造化の指標としては投入係 数, 産出係数及び投入産出額などが考えられる.ただし, FSMにおける指標值は $[0,1]$ でなければならないた め, 産出係数は式 ( 5 ) に示すように域内生産額に移入 額を加えた総需要に対する産出の割合と定義し, 投入産 出額は式（6）に示すようにその最大值で除した相対投 入産出額を用いる必要がある.

$$
\begin{gathered}
\text { 投入係数: } a_{i j}=x_{i j} / X_{j} \ldots \ldots \ldots \ldots \ldots \ldots \ldots \ldots \ldots \\
\text { 産出係数 }: b_{i j}=x_{i j} /\left(X_{i}+m_{i}\right) \ldots \ldots \ldots \ldots \\
\text { 相対投入産出額 }: c_{i j}=x_{i j} / \max \left\{x_{i j}\right\} \\
\text { ここで, } x_{i j} \text { は産出産業 } i \text { と投入産業 } j \\
X_{j}, X_{i} \text { は域内生産額 } \\
m_{i} \text { は移入額 }
\end{gathered}
$$

ここで， $x_{i j}$ は産出産業 $i$ と投入産業 $j$ 間の取引額

投入係数が大きいと言うことは投入産業によって産出 産業加らの原材料の投入への依存が大きく, 投入側産業 にとってこの取引が重要であることを示している. 反対 
に, 産出係数が大きいと言うことは産出産業にとって産 出先産業への依存が大きく, 産出産業にとってこの取引 が重要であることを示している.したがって，交通施設 整備の影響を受けた産業を明確にするためにはこの依存 関係の方向を明らかにしておく必要がある.

投入係数及び産出係数は各産業毎に総投入額または総 産出額で標準化を行っているため, 産業の依存関係は的 確に反映するものの産業の規模は無視される. 一方, 相 対投入産出額は全産業を共通の尺度で標準化しているた め, 産業規模を反映した構造化が可能である.しかし, この指標では依存関係の方向不明となるため, 本研究の 目的には適さない. そこで本研究では分析に用いる指標 として投入係数及び産出係数を採用し, 規模を考慮した 構造化を行うために取引規模の小さいものを分析対象か ら除外することにする.

産業間の依存関係は多くの場合一方方向であるため, 投入係数と産出係数のよ゙ちらか一方を用いることの欠点 は明らかである. 両者を同時に考慮する代表的な方法に は相加平均, 相乗平均及び最大値の 3 種類ある. 本研究 では前述したように産業間の依存方向を明らかにする必 要があるため, 両指標をミックスすることはできない. したがって,ここでは両者の最大值を用いることにする.

\section{(3) 自給率}

高速道路のような地域間の交通施設の影響を考える場 合, 移入品亡地域内品とを区別して扱う必要がある. し かし，各県で作成されている産業連関表は競争型である ため, 産出産業別の総移入額は分かるが投入産業別の移 入額は不明である。ここで, 式 $(7)$ で定義される自給 率が投入産業に拘らず一定であると仮定すると， $i j$ 産業 間の取引のうち域内 $i$ 産業との取引額は式（8）で示さ れる.したがって, 式（9)，(10) により求められる投 入係数は $j$ 産業における域内 $i$ 産業からの投入割合を示 し, 産出係数は域内 $\mathrm{i}$ 産業の $j$ 産業への産出割合を示す ことから，以下では域内投入・産出係数と呼ぶ.

自給率 $: g_{i}=X_{i} /\left(X_{i}+m_{i}\right)$

域内品取引額 : $x_{i j}^{\prime}=g_{i} \cdot x_{i j}$

域内投入係数: $a_{i j}^{\prime}=x_{i j}^{\prime} / X_{j}$

域内産出係数: $b_{i j}^{\prime}=x_{i j}^{\prime} /\left(X_{i}+m_{i}\right)$

域内投入 ·産出係数による構造図 (以下, 域内構造図之 呼ぶ）は域内の産業間の取引関係を表す。したがって, 自給率で補正していない投入・産出係数による構造図 (これは産業間の技術的関係を示すため, 以下, 技術構 造図と呼ぶ）で構造化され，域内構造図で構造化されな い場合, その産業間の取引は域外との取引が大きいこと を示している.

\section{(4) 産業構造の変化}

交通施設整備の効果は輸送時間短縮あるいは輸送費削
減による投入・産出先の変化あるいは新規立地を含む生 産規模の拡大として産業連関構造に影響を与えると考え られる。計量経済モデル等 ${ }^{21)}$,22) は国民経済的便益の計測 を目的としたモデルであり, 操作性の問題から産業部門 数を多くすることが困難である.また，これらのモデル で使用しているグラビティモデルでは交通施設の効果を 経済距離の短縮効果のみで捉えている. これに対し, 構 造化手法を用いた産業構造分析では細分類による産業構 造の変化が分析可能であり, 経済距離短縮以外の効果も 含めた交通施設整備の影響を検討することができる.

投入係数の変化要因には生産技術の変化, 相対価格の 変化, プロダクト・ミックスの変化及び産出量の変化等 があるため ${ }^{1,2}$ 投入・産出係数による構造図の变化はこ れら様々な要因による変化と考えられる. 一方, 交通施 設整備の影響は域外取引の増加や関連産業の立地等によ り自給率の変化として現れる. したがって, 技術構造図 亡域内構造図の違いの変化を分析することによって交通 施設整備との関連を考察することができる.

ただし, 各構造図はその時点における産業間の取引の 相対的な重要度を表すものである. したがって, 構造図 の比較のみで自給率の変化を的確に捉えることはできな い. 交通施設整備の影響を考察するためにはグラフの有 無だけでなく産業間の取引額, 各産業の生産額及び自給 率の変化を交えて考察する必要がある.また，これらの 変化が全て交通施設整備の影響と言うことはできないた め，交通施設整備の影響を定量的に計測するためには産 業構造分析によって抽出された産業に対して実態調査を 行う必要がある.

なお，このような分析は取引額，生産額及び自給率の 変化を直接分析することでも可能であるが，構造図の変 化は重要な取引に変化が生じたか否かを視覚的に把握す ることができ, 重要な取引変化の抽出には有効である. また，域内構造図は域内で充足している産業群や立地を 促すべき産業を視覚的に捉えることができ，産業政策を 考える際の情報提供に役立つと考えている.

\section{3. 産業構造化に関する考察}

\section{（1）従属行列に関する考察}

産業連関表に基づいて産業構造化を行う場合，指標に 投入・産出係数，相対投入産出額のいずれを用いるかに よらず，FSM 法が前提としている従属行列が満たすべ き以下の条件を満足していない.

(1) あいまい非反射律 : $a_{i j}<p$

(2) あいまい非対称律： $a_{i j}<p, a_{j i}<p$ の少なくとも 一方汃成り立つ

(3) あいまい半推移律 : $M=\max _{j}\left\{\min \left(a_{i j}, a_{j k}\right)\right\}$, $M \geqq p$ よき $a_{i k} \geqq M$ ここで, $p$ はあらかじめ設定したしきい値 


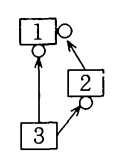

ケース 1

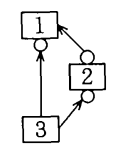

ケース 5

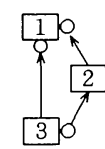

ケース 2

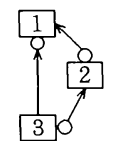

ケース 6

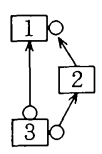

ケース 3

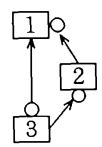

ケース 7
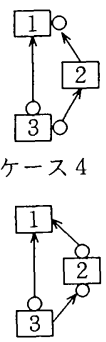

ケース 8

図-1 産業間の従属関係

すなわち，産業連関表はプロダクト・ミックスにより自 部門内取引が大きいため，あいまい非反射律を満たして いない. また，あいまい非対称律，あいまい半推移律に ついても産業間の取引の性質上満たしていない.

あいまい非反射律を満たすように行列を修正するた め, 本研究では自部門内取引を 0 として修正を行う。し かし，この操作により自部門内取引が大きく他産業との 取引が少ない場合，その産業は独立レベルとして構造図 から脱落する．自部門内取引において移出入が多い場合 には交通施設整備の影響を考える上で重要であるが，構 造図に現れず問題である。なお，自部門内取引の問題に ついては，産業部門分類を細かくすることによりその影 響を小さくすることができると考えている.

あいまい非対称律を満たすように $a_{i j}, a_{j i}$ の小さい方 を 0 とする方法, あいまい半推移律を満たすように $a_{i k}$ を $\max _{j}\left\{\min \left(a_{i j}, a_{j k}\right)\right\}$ で置き換える方法などが考えら れる.しかし，これらの置き換えにより実際の産業間の 従属関係とは異なった構造化となってしまう.このため, 本研究ではあいまい非対称律及びあいまい半推移律に関 しては修正を行わないでFSM 法を適用する.

あいまい半推移律を満たさない行列に FSM 法を適用 した場合, 最上層と最下層の要素間に間接的従属関係が あっても直接的従属関係がある保証がなくなるため，最 上層と最下層の直接的従属関係によってブロック分割す る方法では最上層上間接的従属関係しかない最下層がブ ロックから脱落してしまう問題が生じる.そこで本研究 ではブロック分割の際に ISM 法之同様の可達行列を用 い, 本来は間接的従属関係しかない場合にも直接的従属 関係があると考えることによりブロックからの脱落とい う問題を解決した. しかし，あいまい半推移律を満たさ ない従属行列にFSM 法を適用した場合，直接的従属関 係のカットにおいて次のような問題が残されている.

(1) 3 段階以上の間接的従属関係を考慮できない.

(2) 置き換えにより従属関係がカットされるとその カットされる前の間接的従属関係を考慮できなくな る.

表一1 産業構造の変化パターン

\begin{tabular}{|c|c|c|c|}
\hline パターン & 技術構造図 & 域内構造図 & 備 \\
\hline $1 \mathrm{a}$ & $\bigcirc \rightarrow \bigcirc$ & $\bigcirc \rightarrow \times$ & 考 \\
\hline $1 \mathrm{~b}$ & $\bigcirc \rightarrow \bigcirc$ & $\times \rightarrow 0$ & 外 シ 関連産業充足型 \\
\hline $2 \mathrm{a}$ & $\bigcirc \rightarrow \times$ & $\bigcirc \rightarrow \times$ & \\
$2 \mathrm{~b}$ & $\bigcirc \rightarrow \times$ & $\times \rightarrow \times$ & \\
\hline $3 \mathrm{a}$ & $\times \rightarrow \bigcirc$ & $\times \rightarrow \bigcirc$ & 新規立地型 \\
$3 \mathrm{~b}$ & $\times \rightarrow \bigcirc$ & $\times \rightarrow \times$ & 域外取引增加型 \\
\hline
\end{tabular}

○：関係が構造化 $\times$ : 関係が構造化されない

ただし，これらの問題は構造を単純化できないというこ とであり, 本研究のように重要な関係の抽出が目的の場 合には, 重要度の低い関係も抽出される可能性があるが, 重要な関係を漏らすことはなく, 問題はない. ISM 法 等の構造化手法の多くは推移律を前提とした手法である が，FSM 法はこのような改良を行うことで投入係数行 列のような推移律を満たさないものにも適用可能とな る.

\section{（2）単純化に関する考察}

FSM 法により間接的従属関係がある場合に直接的従 属関係をカットしてしまうことの是非について考察す る. 図一1 は 3 産業間の従属関係の組み合わせを示した ものである.ここで, 矢印は財及びサービスの流れを示 し，その指標が投入係数によるものか産出係数によるも のかにより，その関係が○印の付いた産業によってより 重要であることを示している.

FSM 法により産業 3 から産業 1 への直接的従属関係 がカットされた場合，ケース 1 4 亿゙は影響が大きい産 業は同じであり問題ない。一方，ケース 5,6 では産業 1，ケース 7，8 では産業 3 への影響が大きいことが読み 取れなくなってしまう。したがって, 構造図の比較のみ で交通施設整備の影響を論ずる場合にはグラフを単純化 することは好ましくない. しかし，本分析によって抽出 された取引の両側の産業に対して抽出された取引先以外 の産業との取引まで含めた実態調査を行うこととすれ ば，影響の大きな取引の抽出漏れは防ぐことができる.

\section{4. 産業構造変化と交通施設整備の関係}

\section{（1）変化のパターン分類}

FSM 法による構造図を交通施設整備の前後 2 断面で 比較することにより, 交通施設整備と産業間の取引関係, すなわち産業構造の変化との関係を考察することができ る. 構造図には技術構造図と域内構造図の 2 種類がある ため, 産業間の取引関係の有無の組み合わせは全部で $2^{4}=16$ 通りある. しかし, 域内構造図で関係がある場 合には技術構造図でも関係があること，2 断面の各構造 図に変化が見られない場合には産業構造の変化はなかっ たと考えられることから, 本研究では表一1に示す6つ の変化パターンについてのみ考察を加える. 
変化のパターンは，まず，技術構造図の変化により産 業の技術的構造の変化之して分類することができる. 次 に, 域内構造図の変化により地域外亡の取引関係の変化, すなわち交通施設整備との関係を検討することができ る.

\section{（2）パターン 1}

パターン 1 では技術構造図において 2 つの時間断面共 に取引関係が構造化されており，この産業間の取引関係 が強くかつ継続していることが分かる.

パターン1aでは技術構造図で継続している取引関係 が域内構造図ではなくなっており，地域内との取引から 地域外との取引にシフトしたことが分かる.この変化に は交通施設整備による距離抵抗の減少という直接的な影 響が考えられる，ただし，地域内の産出産業にとっては 取引の減少というマイナスの影響となることもある.

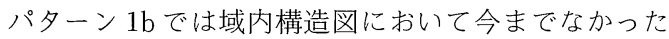
取引関係が新たに生じており，地域内の取引関係が増加 したことが分かる。この地域内取引増加の原因には関連 産業の充足が進んだことが洘えられる. 関連産業の充足 には交通施設整備による立地条件の向上という間接的な 影響が考えられる。

(3) パターン 2

パターン 2 では技術構造図において取引関係が構造化 されなくなっており, 過去に強かった取引関係がその後

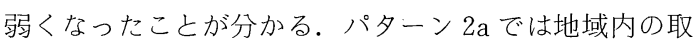

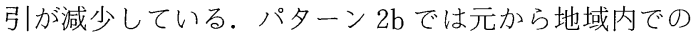
この産業間の関係は弱く，地域外亡の取引が減少してい る。これらは，産業の技術的構造の変化，あるいは産業 自体が衰退してしまったためと考えられ，いずれの場合 も交通施設整備の影響とは考えられない。

\section{（4）パターン 3}

パターン 3 では技術構造図において新たに取引関係が 構造化されており，この産業間の取引関係が増大してい ることが分かる.

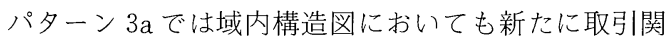
係が構造化されており，産業の技術的構造の変化または 新たな企業立地による変化と考えられる，後者の場合に は交通施設整備による立地条件の向上という間接的な影 響が考えられる.

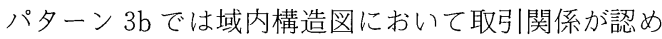
られないままであり, 新たな取引関係の増加が専ら地域 外之の取引増加によるものであることが分かる.この変 化には交通施設整備による距離抵抗の減少という直接的 な影響が考えられる.しかも新たな取引関係であるため, パターン $1 \mathrm{a}$ とは異なり産出産業・投入産業ともにプラ スの影響と言える。

\section{5. 適 用 例}

\section{（1） 分析の概要}

適用例として, 昭和 50 年代に東北自動車道及び東北 新幹線が整備された宮城県と岩手県, 及びこれらの交通 施設から離れた山形県と秋田県の 4 県を対象に産業構造 の前後比較を行った. 使用したデー夕は昭和 50 年及び 昭和 60 年の各県産業連関表である. 部門数はそれぞれ 異なっており，前後比較並びに地域間比較を行うため各 表とも 52 部門に統合した.

投入係数及び産出係数の最大値を用いて FSM 法によ る構造化を行った．規模の小さな取引を除外するため, 取引額が県内総生産額の $0.1 \%$ 上り少ないものはカット した．この結果，分析に用いた取引関係は各表とも 100 程度となった。しきい値はグラフが交錯しない程度とし て $p=0.096(=5 / n)$, あいまい構造パラメー夕は産業 の抽出にもれがなければよいと考え $\lambda=87.4(k=1)$ と した．各県の構造図の変化は付録に示している.

以下では，構造図の変化 6 パターンのうち, 交通施設 整備の影響が考えられるパターン $1 \mathrm{a} ， 1 \mathrm{~b} ， 3 \mathrm{a}$ 及び $3 \mathrm{~b}$ についてパターン別に考察を行う．考察では交通施設整 備の影響をより明確にするため, 県内総生産額の伸び率 に対する取引額及び生産額の伸び率（以下，相対伸び率 という）及び自給率を交えて考察を行う。

（2）域外シフト型変化（パターン 1a)

表一2 はパターン $1 \mathrm{a}$ の変化の現れた産業間の関係を 示している.この中には, 交通施設整備による距離抵抗 の減少という直接的な影響により, 取引が域内から域外 との取引にシフトしたケースが考えられる.

宮城県の「石油・石炭製品 $\rightarrow$ 運輸」では取引の相対伸 び率が横ばいであり，石油・石炭製品の自給率が減少し ていることから，取引規模はほとんど変化せずに取引先 が域内から域外へシフトしていることが分かる.

山形県の「非鉄金属製品 $\rightarrow$ 電気機械」では非鉄金属製 品の自給率が減少しており, 取引の域外へのシフトが見 られる.さらに, この取引の相対伸び率が高く, 両産業 の県内生産額の相対伸び率も高いことから，これらの産 業の充足も進んだと言える.

一方，パターン $1 \mathrm{a}$ の変化の中には産業間の取引が相 対的に減少し，技術構造図では残っている関係が域内構 造図では消滅したケースもある. 宮城県, 山形県の上述 以外の変化及び岩手県, 秋田県での変化はいずれもこの ようなケースであり，これらの変化は交通施設整備の影 響ではなく産業の技術的構造の変化によるものである.

（３）関連産業充足型変化（パ夕ーン $1 \mathrm{~b}$ )

表一3 はパターン $1 \mathrm{~b}$ の変化の現れた産業間の関係を 示している.この変化の中には, 交通施設整備による立 地条件の向上という間接的な影響により，地域内におい 
表一 2 域外シフト型変化

\begin{tabular}{|c|c|c|c|c|c|}
\hline \multirow{2}{*}{ 県 } & \multirow{2}{*}{ 変化した産業間の関係 } & \multirow{2}{*}{$\begin{array}{c}\text { 取引 } \\
\text { 伸び }\end{array}$} & \multirow{2}{*}{$\begin{array}{l}\text { 自給率変化 } \\
\text { (産出) \% }\end{array}$} & \multicolumn{2}{|c|}{ 県内生産伸び } \\
\hline & & & & 産 出 & 投 入 \\
\hline \multirow{4}{*}{$\begin{array}{c}\text { 宮 } \\
\text { 城 }\end{array}$} & $\sigma^{\prime}$ & 0.48 & $50 \rightarrow 48$ & 0.64 & 0.81 \\
\hline & & 7 & $35 \rightarrow 32$ & 0.56 & 0.71 \\
\hline & 石油·石岩 & 0.43 & $54 \rightarrow 46$ & 0.70 & 1.22 \\
\hline & 石油・入 & 0.95 & $54 \rightarrow 46$ & 0.70 & 0.89 \\
\hline \multirow[t]{2}{*}{ 山 } & 飲料 $\rightarrow$ 他 & 0.48 & $57 \rightarrow 44$ & 0.49 & 0.82 \\
\hline & 基礎化学 & 0.26 & $39 \rightarrow 34$ & 0.65 & 0.58 \\
\hline 形 & 非鉄 & 2.02 & $63 \rightarrow 50$ & 2.67 & 2.96 \\
\hline \multirow{3}{*}{ 岩 } & 耕種農 & 0.42 & $89 \rightarrow 88$ & 0.69 & 0.45 \\
\hline & 基礎化学 & 0.48 & $51 \rightarrow 46$ & 0.67 & 0.69 \\
\hline & 金属鉱物一 & 0.52 & $33 \rightarrow 16$ & 0.29 & 0.41 \\
\hline \multirow[t]{2}{*}{ 手 } & 石油・石炭 & 0.57 & $26 \rightarrow 19$ & 0.58 & 0.90 \\
\hline & 輸送機械一 & 0.63 & $40 \rightarrow 42$ & 0.79 & 0.90 \\
\hline 秋 & 耕種農 業一 & 0.68 & $85 \rightarrow 90$ & 0.66 & 0.97 \\
\hline 田 & 石油·石炭製品 $\rightarrow$ 運輸 & 0.59 & $34 \rightarrow 19$ & 0.87 & 0.90 \\
\hline
\end{tabular}

表-3 関連産業充足型変化

\begin{tabular}{|c|c|c|c|c|c|}
\hline \multirow{2}{*}{ 県 } & \multirow{2}{*}{ 変化した産業間の関係 } & \multirow{2}{*}{$\begin{array}{c}\text { 取引 } \\
\text { 伸び }\end{array}$} & \multirow{2}{*}{$\begin{array}{l}\text { 自給率変化 } \\
\text { (産出) \% }\end{array}$} & \multicolumn{2}{|c|}{ 県内生産伸び } \\
\hline & & & & 産 出 & 投 入 \\
\hline 山形 & 他化学製品 $\rightarrow$ 医療・保障 & 1.47 & $34 \rightarrow 49$ & 2.40 & 1.03 \\
\hline 岩 & 繊維製品 $\rightarrow$ 衣服・他繊維 & 2.37 & $39 \rightarrow 32$ & 0.71 & 2.22 \\
\hline 手 & 出版・印刷 $\rightarrow$ 他サービス & 2.21 & $46 \rightarrow 52$ & 1.25 & 1.28 \\
\hline 秋 & 蟣維製品 $\rightarrow$ 衣服・他䋐維 & 2.56 & $24 \rightarrow 25$ & 0.81 & 3.01 \\
\hline & 運輸 $\rightarrow$ 非金属鉱物 & 2.02 & $81 \rightarrow 90$ & 0.90 & 1.69 \\
\hline 田 & 運翰 $\rightarrow$ 商業 & 0.99 & $81 \rightarrow 90$ & 0.90 & 1.17 \\
\hline
\end{tabular}

表一4 新規立地型変化

\begin{tabular}{|c|c|c|c|c|c|}
\hline \multirow{2}{*}{ 県 } & \multirow{2}{*}{ 変化した産業間の関係 } & \multirow{2}{*}{$\begin{array}{l}\text { 取引 } \\
\text { 伸び }\end{array}$} & \multirow{2}{*}{$\begin{array}{l}\text { 自粭率変化 } \\
\text { (産出) \% }\end{array}$} & \multicolumn{2}{|c|}{ 県内生産伸び } \\
\hline & & & & 産 出 & 投 入 \\
\hline \multirow[t]{2}{*}{ 宮 } & 出版・印刷 $\rightarrow$ 他サービス & 3.32 & $65 \rightarrow 65$ & 1.23 & 1.31 \\
\hline & 不動産 $\rightarrow$ 商業 & 1.43 & $100 \rightarrow 100$ & 1.15 & 1. 10 \\
\hline \multirow[t]{3}{*}{ 城 } & 運翰 $\rightarrow$ 商業 & 1.32 & $89 \rightarrow 86$ & 0.89 & 1. 10 \\
\hline & 精穀・製粉 $\rightarrow$ 他食料品 & 1.03 & $92 \rightarrow 100$ & 0.77 & 0.77 \\
\hline & 翰送機械 $\rightarrow$ 運翰 & 8.04 & $15 \rightarrow 49$ & 3.54 & 3. 49 \\
\hline \multirow[t]{3}{*}{..L } & 運翰 $\rightarrow$ 玄産・養蚕 & 3.40 & $70 \rightarrow 95$ & 3.49 & 0.48 \\
\hline & 運輸 $\rightarrow$ 非金属鉱物 & 9.93 & $70 \rightarrow 95$ & 3.49 & 0.51 \\
\hline & 金融·保険 $\rightarrow$ 商業 & 1.20 & $98 \rightarrow 94$ & 0.79 & 0.83 \\
\hline \multirow[t]{3}{*}{ 形 } & 商業 $\rightarrow$ 衣服・他織維 & 2.63 & $73 \rightarrow 66$ & 0.83 & 2.02 \\
\hline & 不動産 $\rightarrow$ 他サービス & 1.92 & $100 \rightarrow 100$ & 0.79 & 0.82 \\
\hline & 公サービス $\rightarrow$ 他サービス & 14.2 & $100 \rightarrow 100$ & 1.03 & 0.83 \\
\hline 岩手 & 農業サービス $\rightarrow$ 畜産・盖蚕 & 2.62 & $99 \rightarrow 100$ & 1.39 & 0.95 \\
\hline 秋 & 非鉄金属製品 $\rightarrow$ 電気機械 & 3.33 & $84 \rightarrow 76$ & 0.59 & 4.06 \\
\hline 田 & 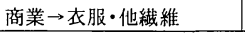 & 16.6 & $86 \rightarrow 91$ & 1.17 & 3.01 \\
\hline
\end{tabular}

て関連産業の充足が進んだケースが考えられる.

山形県の「その他化学製品 $\rightarrow$ 医療・保障」, 岩手県の 「出版・印刷 $\rightarrow そ の$ 他サービス」では産出産業の県内生 産額の相対伸び率が高く, 自給率も増加していることか ら, これら産出産業の充足が進み域内取引が増加したと 言える。

秋田県の「運輸 $\rightarrow$ 非金属鉱物」,「運輸 $\rightarrow$ 商業」の場合 も運輸の自給率が増加しており, 域内からの投入が増加 している. しかし, 運輸の県内生産額は相対的に減少し ており，運輸が充足したものではない.

岩手県及び秋田県の「繊維工業製品 $\rightarrow$ 衣服・その他繊 維製品」では取引の相対伸び率が高く, 産業間の関係が 強まっている. しかし, 繊維工業製品の県内生産額は両 県とも相対的に減少しており，この変化は繊維工業製品 の充足が進んだものではなく，技術的構造の変化による ものである.
表一5 域外取引増加型変化

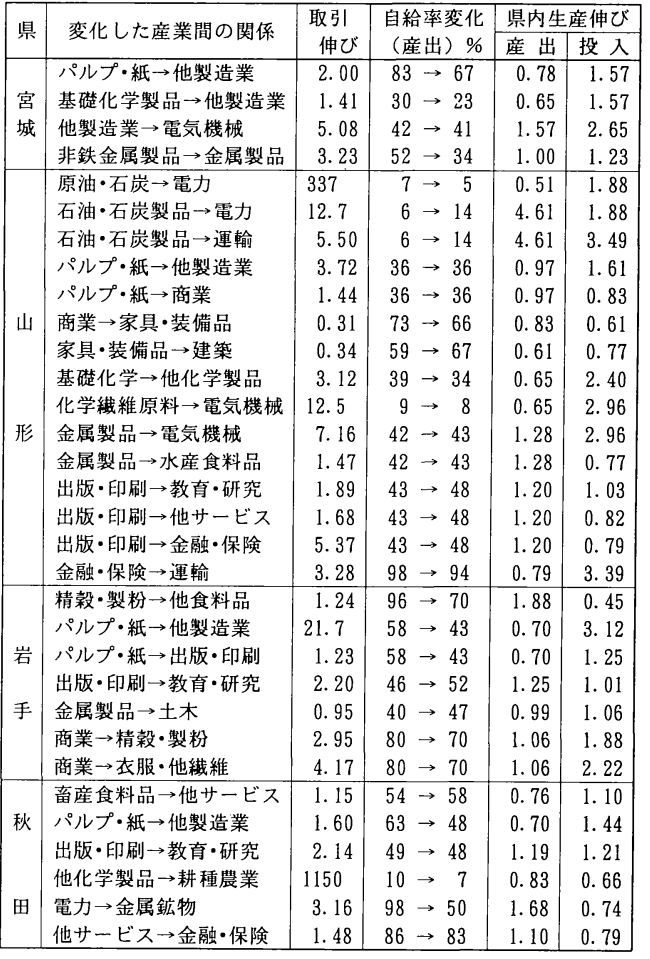

（4）新規立地型変化（パターン $3 a ）$

表一4 はパターン $3 \mathrm{a}$ の変化の現れた産業間の関係を 示している.この変化の中には, 交通施設整備による立 地条件の向上という間接的な影響により，新たな企業立 地が進んだケースが考えられる.

山形県の「輸送機械 $\rightarrow$ 運輸」, 「運輸 $\rightarrow$ 畜産・養虫」, 「運 輸 $\rightarrow$ 非金属鉱物」, 秋田県の「商業 $\rightarrow$ 衣服・その他繊維 製品」では取引の相対伸び率が非常に高く, 産出産業の 自給率も増加しており, 域内の取引増加が著しい. また, 輸送機械, 運輸及び衣服・その他繊維製品の県内生産額 の相対伸び率も非常に高く, これらの産業の立地が進ん だと考えられる.

秋田県の「非鉄金属製品 $\rightarrow$ 電気機械」も取引の相対伸 び率が非常に高く, 産業間の関係が強まっている. 非鉄 金属製品の県内生産額は相対的に減少しており, 自給率 も減少していることから，域外との取引増加が著しいこ とが分かる. 一方, 電気機械の県内生産額の相対伸び率 は非常に高く, 電気機械の立地が進んだと考えられる.

宮城県の「出版・印刷 $\rightarrow$ そ他サービス」, 山形県の「商

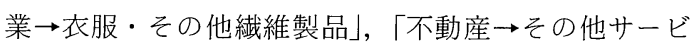
ス」,「その他公共サービス $\rightarrow$ の他サービス」, 岩手県 の「農業サービス $\rightarrow$ 畜産・養虫」では取引の相対伸び率 は非常に高いが，各産業の県内生産額の相対伸び率はそ れほど高くなく，これらの変化は技術的構造の変化によ るものである. また, 上述以外の変化については指標の 
表一6 交通施設整備の影響による構造変化

\begin{tabular}{|c|c|c|c|c|}
\hline パターン & 宮 城 & 山 形 & 岩 手 & 秋 \\
\hline 域外シフト型 & 石油・石炭製品 $\rightarrow$ 運輸 & 非鉄金属製品 $\rightarrow$ 要気機械 & & \\
\hline 関連産業充足型 & & 他化学製品 $\rightarrow$ 医療·保障 & 出版·印刷 $\rightarrow$ 他サービス & \\
\hline 新規立地型 & & 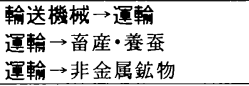 & & 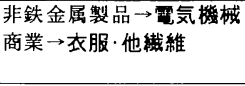 \\
\hline 域外取引増加型 & 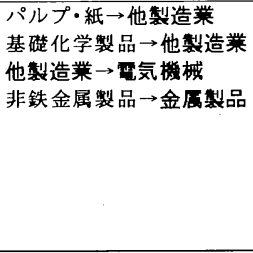 & 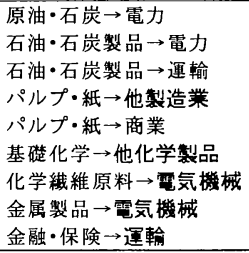 & 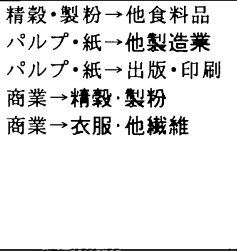 & $\begin{array}{l}\text { パルプ・紙 } \rightarrow \text { 他製造業 } \\
\text { 電力 } \rightarrow \text { 金属鉱物 }\end{array}$ \\
\hline
\end{tabular}

注）太字は立地が進んだことが考えられる産業を示す。

変化は比較的小さく，大きな変化ではなかった。

（5）域外取引増加型変化（パターン $3 b$ )

表一 5 はパターン $3 \mathrm{~b}$ の変化の現れた産業間の関係を 示している.この変化の中には, 交通施設整備による距 離抵抗の減少という直接的な影響により, 地域外との取 引が新たに増加したケースが考えられる.

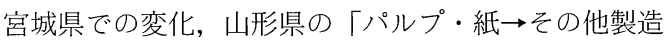
業」, 「基礎化学製品 $\rightarrow$ その他化学製品」，「化学繊維原料 $\rightarrow$ 電気機械」, 「金属製品 $\rightarrow$ 電気機械」, 「金融・保険 $\rightarrow$ 運

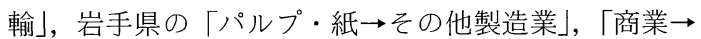
精穀・製粉」，「商業 $\rightarrow$ 衣服・その他繊維製品」では取引 が増大しているのに対し, 産出産業の自給率は横ばいか 減少しており，域外との取引が急激に増大していること が分かる. また，投入産業の県内生産額も増大しており， 交通施設整備による輸送抵抗の減少により投入産業の立 地が進んだことが考えられる。

岩手県の「精穀・製粉 $\rightarrow そ の$ 他食料品」，「パルプ・紙 $\rightarrow$ 出版・印刷」, 秋田県の「パルプ・紙 $\rightarrow$ そ他製造業」, 「電力 $\rightarrow$ 金属鉱物」では取引の相対伸び率が高く, 産出 産業の自給率が大幅に減少しており，域外との取引が増 加している. ただし, 各産業の県内生産額の相対伸び率 はそれほど高くなく，これらの変化は産業の立地による ものではない. また, 山形県の「原油・石炭 $\rightarrow$ 電力」, 「石 油・石炭製品 $\rightarrow$ 電力」, 「石油・石炭製品 $\rightarrow$ 運輸」も取引 の相対伸び率が高く,産出産業の自給率が低いことから, 域外との取引増加が著しい.

山形県の「パルプ・紙 $\rightarrow$ 商業」，「出版・印刷 $\rightarrow$ 金融・ 保険」, 「出版 - 印刷 $\rightarrow$ 教育 - 研究」, 「出版印刷 $\rightarrow$ その他 サービス」，「金属製品 $\rightarrow$ 水産食料品」，岩手県の「出版・ 印刷 $\rightarrow$ 教育 - 研究」, 秋田県の「畜産食料品 $\rightarrow$ その他サ一 ビス」, 「その他化学製品 $\rightarrow$ 耕種農業」, 「出版・印刷 $\rightarrow$ 教 育・研究」，「その他サービス $\rightarrow$ 金融・保険」では取引の 相対伸び率は高いが，各産業の県内生産額及び産出産業 の自給率の変化は小さく, 技術的構造の変化によるもの である. また，上述以外の変化については取引の相対伸 び率が低く，大きな変化ではなかった。

\section{（6）交通施設整備の影響}

以上の分析によって，交通施設整備の影響による産業 構造の変化をまとめたのが表一6である.

山形県に交通施設整備の影響と思われる構造変化が多 くみられる. 特に, 電気機械に関連した取引に変化が多 く, また, 電気機械及び運輸の生産額も急増しており, 交通施設整備によって電気機械の立地が進んだとともに 域外との取引が増加したと考えられる。

宮城県及び岩手県では電気機械やその他製造業などに 関連して域外との取引が増加しており，これらの産業に 交通施設整備の影響が考えられる。実際，宮城県におい ては電気機械がこの期間に高速道路沿線へ立地してお り，このことが構造図の変化となって現れている.

秋田県においては電気機械の立地が見られるものの, そのほかの構造変化が少なく, 交通施設整備の影響は限 定されたものと考えられる.

宮城県や岩手県は高速道路や新幹線の沿線であるため 交通施設整備の影響が大きく, 秋田県はそれら交通施設 から離れているために影響が小さいのは当然と言えよ う。一方，高速道路や新幹線から離れている山形県の方 が岩手県より多くの構造変化がみられるのは, 首都圏と の時間距離では山形県の方が岩手県より近い地域も多 く, 首都圏の企業にとって山形県の方がより魅力的にみ えることが一因と考えられる。

東北 4 県のこの期間の産業構造変化には新規立地に伴 う域外取引の増加と考えられるパターンが多く, 域内で の関連産業が充足と考えられるパターンは少ない．この ような変化は地域への波及効果を考えた場合, 域外への 効果の流出が大きいことになる，したがって，地域開発 を考える場合には，域内産業構造図で欠落した産業の充 足を図るような政策を進めてゆく必要があろう.

\section{6. 結 論}

本研究は構造化分析を用いることにより交通施設整備 と地域の産業構造の変化との関係を明確にすることを目 的としていた。本研究で得られた主たる結論は以下のよ 
うにまとめられる。

(1) 産業連関表に基づいて地域の産業構造を分析する 際に，FSM 法はしきい値とあいまい構造パラメータ の值を変えることによりその分析目的に応じた構造化 が行えることを示した。

(2) 産業連関表に FSM 法を適用する場合, 従属行列 の性質及び構造単純化に若干の問題が生じるが，交通 施設整備之の関係を検討する際のこれらの問題への対 処方法を示した.

(3) 投入 ・産出係数の最大值加得られた技術構造図 及び自給率を考慮した域内構造図の変化をパターン分 類することにより, 交通施設整備の影響を受けたと思 われる産業間の関係を抽出できることを示した.また， 交通施設整備に関連した変化のパターンとしては「域 外シフト型」,「関連産業充足型」,「新規立地型」,「域 外取引増加型」の 4 つがあることを示した。

(4) 抽出された産業間の関係に対して, 生産額, 自給 率及び取引額の情報を加えて分析することにより，交 通施設整備と産業構造変化との関係を明らかにするこ とができることを示した。

適用例として, 東北 4 県に本研究の分析法を適用した。 分析の結果, 電気機械等を中心に交通施設整備の影響に よる新規立地と考えられる構造変化パターンがみられた 一方で域内での関連産業の充足が進んでいないことが明 らかになった。

しかし，今回の分析は交通施設整備の影響が考えられ る産業を抽出するにとどまるものであり，交通施設整備 の影響をより明確にするためには，抽出された産業間の 関係について実態調查を行う必要がある. また, 構造化 手法自体にもあいまい半推移律を満たさない行列に対す る対処法やパラメータの設定方法, さらには構造変化に おける交通施設整備以外の要因の排除亡いった課題が残 されている.

\section{参 考 文 献}

1) A.P. Carter and A. Brody (eds.) : Applications of Input-Output Analysis, North-Holland Publishing Company, Vol.2, pp.207 302, 1970.

2) A. Brody and A.P. Carter (eds.) : Input-Output Techniques, North-Holland Publishing Company, pp.343 417, 1972.

3) J.J. Buckley : Fuzzy input-output analysis, European Journal of Operational Research, Vol.39, pp.54 60, 1989.
4) W. Leontief : Structure Change, Studies in the Structure of the American Economy, Oxford University Press, pp.17 52, 1953.

5) A.O. Hirschman : The Strategy of Economic Development, Yale University Press, 1958.

6) P.N. Rasmussen : Studies in Inter-sectoral Relations, North-Holland Publishing Company, 1956.

7) H.B. Chenery and T. Watanabe : International Comparison of the Structure of Production, Econometrica, 1958.

8）金子敬生：産業構造諭, 世界思想社, pp. 1 86, 1983.

9) W. Leontief : Dynamic Analysis, Studies in the Structure of the American Economy, Oxford University Press, pp. 53 $\sim 90,1953$.

10) M. Morishima : Prices, Interest and Profits in a Dynamic Leontief System, Econometrica, Vol.26, pp.358 380, 1958.

11) R.M. Solow : Competitive Valuation in a Dynamic Input-Output System, Econometrica, Vol.27, pp.30 53, 1959.

12) W. Leontief : The dynamic inverse, Contributions to Input-Output Analysis, North-Holland Publishing, pp.17 $\sim 46,1970$.

13）尾崎嚴: 経済発展の構造分析 (一), 三田学会雑誌, Vol. 72, No.6, pp. 84 112, 1979.

14) J. Campbell : Application of Graph Theoretic Analysis to Interindustry Relationships, Journal of Regional Science and Urban Economics, No.5, pp.91 106, 1975.

15) P.B. Slater : The Determination of Groups of Functionally Integrated Industries in the United States Using a 1967 Interindustry Flow Table, Empirical Economics, Vol.2, Issue 1, pp.1 9, 1977.

16）稲村 肇・馬場 聡・徳永幸之：産業連関表に基づく産 業立地分析, 土木計画学論文集, No. 9, pp. 229 236, 1991.

17）本多中二・大里有生：ファジィ工学入門, 海文堂出版, 1989.

18）椹木・河村：参加型システムズ・アプローチ, 日刊工業 新聞社, pp. 36〜 42, 1981.

19）田崎栄一朗：あいまい理論による社会システムの構造化, 別冊「数理科学」ファジイ理論への道, pp. 140 153, 1988.

20) E. Fontela and A. Gabus : "DEMATEL Report, Analytical Methods", Battelle Geneva Research Centre, 1973.

21）坂下・佐々木・松尾・山根・国久：グローバル・メッ ツ・モデルによる交通投資効果の分析, 地域学研究, Vol. 4, pp. 51 71, 1974.

22）目良浩一：交通投資の地域開発効果予測のためのモデル 作成の試み, 地域学研究, Vol.11, pp.1〜15, 1981.

(1992.9.7 受付) 


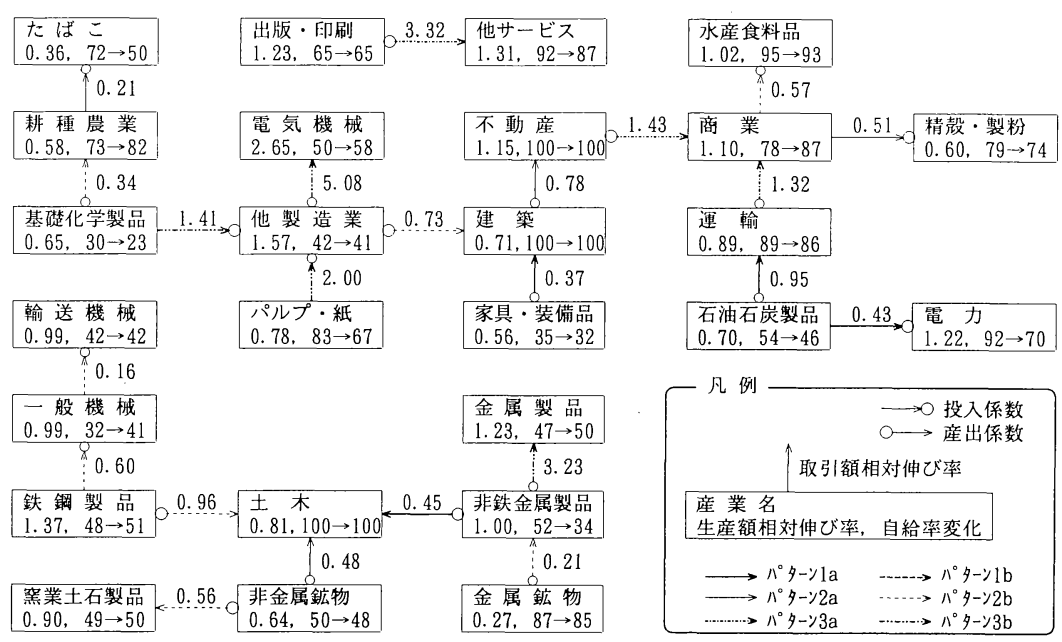

付図一1宮城県の産業構造変化 $(1975 \rightarrow 1985)$

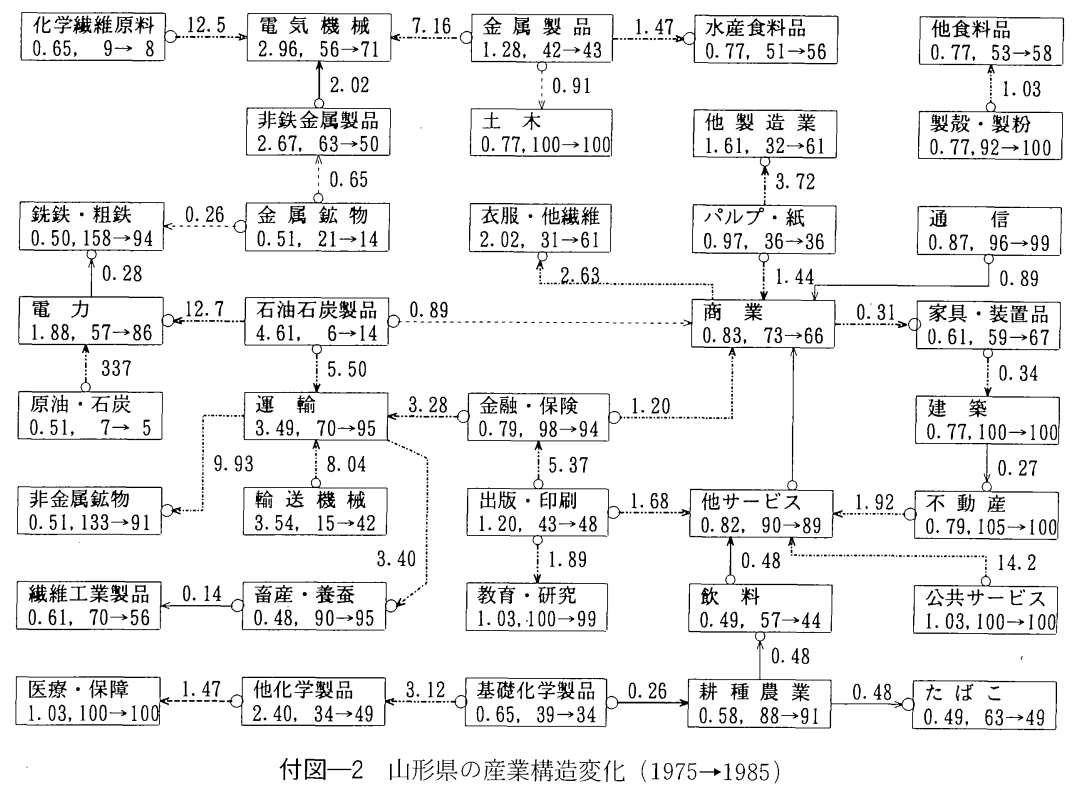




\begin{tabular}{|c|c|c|c|c|c|c|c|}
\hline $\begin{array}{l}\text { 他サービス } \\
1.28,85 \rightarrow 81\end{array}$ & & \begin{tabular}{|l|} 
農業サービス \\
$1.39,99 \rightarrow 100$
\end{tabular} & 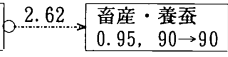 & & $\begin{array}{l}\text { その他食料品 } \\
0.45,40 \rightarrow 30\end{array}$ & & $\begin{array}{l}\text { 领 料 } \\
0.65,50 \rightarrow 28\end{array}$ \\
\hline 2.21 & & & & & $1.24 \stackrel{\mathrm{T}}{!}$ & 0.42 & 0.47 \\
\hline $\begin{array}{l}\text { 出版 } \cdot \text { 印刷 } \\
1.25,46 \rightarrow 52\end{array}$ & 2.20 & \begin{tabular}{|l|} 
\\
教育 ·研究 \\
$1.01,100 \rightarrow 100$
\end{tabular} & $\begin{array}{l}\text { 衣服・他織維 } \\
2.22, \quad 33 \rightarrow 47 \\
\end{array}$ & & $\begin{array}{l}\text { 製敦・製粉 } \\
1.88, .96 \rightarrow 70\end{array}$ & & $\begin{array}{l}\text { 耕種 農業 } \\
0.69,89 \rightarrow 88\end{array}$ \\
\hline 1.23 & & & 2.37 & 4.17. & 2.95 & & 0.48 \\
\hline $\begin{array}{l}\text { パルプ. 紙 } \\
0.70, \quad 58 \rightarrow 43 \\
\end{array}$ & $21.7 \underset{\Rightarrow 0}{0}$ & \begin{tabular}{|l|l|l|l} 
他製 造 業 \\
$3.12, \quad 19 \rightarrow 34$ \\
\end{tabular} & $\begin{array}{l}\text { 織維工業製品 } \\
0.71,39 \rightarrow 32 \\
\end{array}$ & & $\begin{array}{l}\text { 商業 } \\
1.06,80 \rightarrow 69\end{array}$ & & $\begin{array}{l}\text { 基䃈化学製品 } \\
0.67,51 \rightarrow 46\end{array}$ \\
\hline 0.60 & & & & & & & \\
\hline $\begin{array}{l}\text { 製材 } \cdot \text { 木製品 } \\
0.62,78 \rightarrow 91 \\
\end{array}$ & & \begin{tabular}{|l|} 
非鉄金属製品 \\
$1.80,14 \rightarrow 25$
\end{tabular} & $\begin{array}{l}\text { 運 輸 } \\
0.90,76 \rightarrow 83 \\
\end{array}$ & 0.57 & 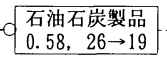 & 0.36 & \begin{tabular}{|l|} 
筀業土石製品 \\
$0.78,78 \rightarrow 73$ \\
\end{tabular} \\
\hline & & 0.14 & 0.63 & & & & 0.87 \\
\hline $\begin{array}{l}\text { 建 築 } \\
0.72,100 \rightarrow 100 \\
A\end{array}$ & & \begin{tabular}{|l|} 
土 木 \\
$1.06,100 \rightarrow 100$
\end{tabular} & $\begin{array}{l}\text { 輸送 楲械 } \\
0.79,40 \rightarrow 42 \\
\end{array}$ & & $\begin{array}{l}\text { 鉄鉄・粗鎆 } \\
0.41, .93 \rightarrow 83\end{array}$ & 0.38 & \begin{tabular}{|l|} 
電 力 \\
$2.22,34 \rightarrow 55$
\end{tabular} \\
\hline 0.41 & & 0.95 & 0.66 & & 0.52 & & 0.25 \\
\hline $\begin{array}{l}\text { 家具・装置品 } \\
0.66,24 \rightarrow 25 \\
\end{array}$ & & \begin{tabular}{|l|} 
金属製品 \\
$0.99,40 \rightarrow 47$ \\
\end{tabular} & \begin{tabular}{|l|} 
㕕么製品 \\
$1.87, \quad 12 \rightarrow 15$
\end{tabular} & & $\begin{array}{l}\text { 金属鉱 物 } \\
0.29,33 \rightarrow 16 \\
\end{array}$ & & \begin{tabular}{|l|} 
電気 機械 \\
$2.32,46 \rightarrow 60$ \\
\end{tabular} \\
\hline
\end{tabular}

付図一3 岩手県の産業構造変化 $(1975 \rightarrow 1985)$
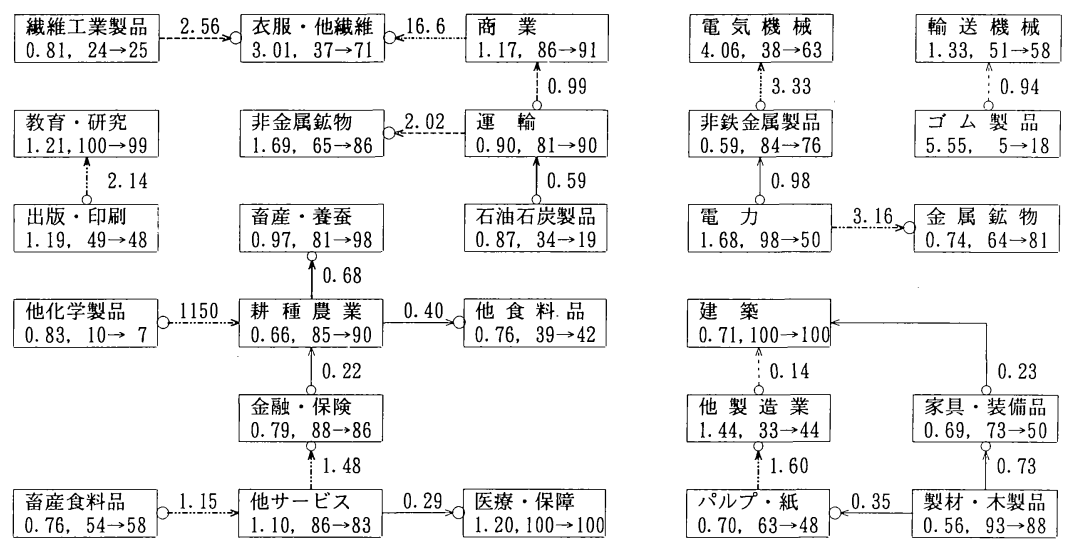

付図一4 秋田県の産業構造変化 $(1975 \rightarrow 1985)$

\section{THE RELATION BETWEEN THE CHANGES OF INPUT-OUTPUT STRUCTURE AND} THE NEW TRANSPORTATION FACILITIES

Yoshiyuki TOKUNAGA, Hajime INAMURA, Hiroshi SUDA and Sei-ichiroh YASUI

This paper discusses the relation between the changes of Input-Output structure and the improvement of transportation facilities. The fuzzy structural modeling method is applied for structuring of interindustry transaction. The maximum value of the input coefficient and output coefficient of Input-Output Tables are used for this purpose. The rate of intraregion trade plays a great role to identify the changes of interregional interdependence of industries. The relation between the changes of Input-Output structure and the improvements of transportation facilities, suchas expressway, are discussed by comparing the Input-Output structure before and after these projects. 